\title{
UPAYA PREVENTIF DAN KURATIF DEMAM BERDARAH MELALUI PEMANFAATAN HERBAL BERKHASIAT DI DESA GADINGAN KABUPATEN SUKOHARJO PROVINSI JAWA TENGAH
}

\author{
Crescentiana Emy Dhurhania $^{1 *}$, Agil Novianto ${ }^{1}$ \\ ${ }^{1}$ Program Studi DIII Farmasi, Sekolah Tinggi Ilmu Kesehatan Nasional, Surakarta, Indonesia \\ *Penulis korespondensi: dhurhania@ stikesnas.ac.id
}

\begin{abstract}
Abstrak
Desa Gadingan yang berada di kecamatan Mojolaban, Kabupaten Sukoharjo merupakan salah satu desa yang mengalami kenaikan prevalensi Demam Berdarah Dengue (DBD) tertinggi di Provinsi Jawa Tengah. Hal ini didukung dengan rendahnya pola perilaku dan fasilitas untuk sanitasi dan higienitas warga. Rendahnya tingkat pengetahuan mengurangi kesadaran tentang bahaya DBD. Program ini dilakukan sebagai upaya preventif dan kuratif DBD melalui pemanfaatan herbal berkhasiat yang merupakan potensi wilayah menjadi produk berbasis herbal. Pengabdian masyarakat dengan mitra Kismosari dan Badran desa Gadingan diawali dengan melakukan edukasi DBD dan pemanfaatan herbal berkhasiat, dilanjutkan dengan pelatihan herbal berkhasiat. Potensi herbal berkhasiat wilayah tersebut diaplikasikan dengan pembuatan produk yaitu mosquito repellent patch, granul herbal larvasida dan teh herbal. Produksi dilakukan oleh warga kedua mitra dengan pendampingan tim pelaksana melibatkan mahasiswa dan stakeholder. Monitoring evaluasi terhadap program edukasi dilakukan dengan pretest dan posttest. Pengembangan produk dilakukan dengan melihat hasil evaluasi mitra pada saat pelaksanaan pelatihan herbal berkhasiat. Pelaksanaan program mampu memberikan perubahan tingkat pengetahuan masyarakat secara signifikan. Hal ini juga didukung dengan penurunan angka kejadian DBD di desa Gadingan pada tahun 2017. Evaluasi pengembangan produk diperoleh hasil 55,68 \% teh herbal; 30,68 \% mosquito repellent patch dan 13,64\% granul larvasida. Pengembangan produk teh herbal dilakukan di Kismosari sedangkan mosquito repellent patch di Badran.
\end{abstract}

Kata kunci: DBD, Mosquito Repellent Patch, Herbal Larvasida, Teh Herbal, Gadingan

\begin{abstract}
Gadingan village which is located in Sukoharjo district of Mojolaban is one of the highest prevalence of dengue fever in Central of Jawa. It is supported with the low of behaviour and facilities for sanitation and hygiene of villagers. The low level of knowledge reduces awareness about the dangers of DBD. This program is conducted as preventive and curative DBD efforts through the utilization of nutritious herbs that are potential of the region to be herbal based products. Community service with partners Kismosari and Badran in Gadingan village begins by educating DBD and utilization of nutritious herbs, continued with a nutritious herbs workshop. Potential herbs of that region are applied with the manufacture of products, that is mosquito repellent patch, herbal larvacide granule and herbal tea. The production is done by the villagers of two partners with accompaniment by the implementing team involving students and stakeholders. Monitoring of evaluation of education program is done by pretest and posttest. Product development is done by looking at partners evaluation result during the nutritious herbs workshop. Implementation of the program is able to provide significant changes in the level of community knowledge. It is also supported by the decrease in the incidence of DBD at Gadingan in 2017. Evaluation of product development obtained results $55.68 \%$ herbal tea; $30.68 \%$ mosquito repellent patch and $13.64 \%$ granule larvacide. Herbal tea product development is done in Kismosari while mosquito repellent patch in Badran.
\end{abstract}

Keywords: Dengue Fever, Mosquito Repellent Patch, Herbal Larvacide, Herbal Tea, Gadingan 


\section{PENDAHULUAN}

Penyakit Demam Berdarah Dengue (DBD) masih merupakan permasalahan serius di Provinsi Jawa Tengah, terbukti 35 kabupaten/kota sudah pernah terjangkit penyakit DBD. Angka kesakitan/Incidence Rate (IR) kasus DBD di Provinsi Jawa Tengah pada tahun 2009 sebesar 5,74/10.000 penduduk (Dinkes Jateng, 2009). Kabupaten Sukoharjo merupakan daerah endemis demam berdarah dengan Case Fatality Rate (CFR) yang tinggi bila dibandingkan dengan standar nasional. Angka kejadian DBD pada tahun 2011 yaitu 106 kasus dengan kematian 1 orang (CSR 0,94\%), sedangkan bila dibandingkan dengan 3 tahun kemudian yaitu pada tahun 2014 angka kejadian DBD naik menjadi 220 kasus yang tersebar hampir di setiap kecamatan di kabupaten Sukoharjo dengan kasus kematian sebanyak 10 orang dengan nilai CFR sebesar 4,5\% atau naik 5 kali lipat dibandingkan tahun 2011.

Berdasarkan data yang diperoleh dari Dinas Kesehatan Kabupaten Sukoharjo, Mojolaban menjadi salah satu daerah dengan angka kejadian DBD yang tinggi. Salah satu desa di kecamatan Mojolaban yang sampai pada tahun 2016 menunjukkan prevalensi DBD yaitu desa Gadingan. Hasil interview yang melibatkan beberapa warga dan bidan yang bertugas di Poli Klinik Desa (PKD) Gadingan diperoleh data naiknya angka kejadian penderita DBD dengan 4 kasus pada bulan Mei 2016 di wilayah Badran (Rt 3 Rw 4) dan 2 kasus di wilayah Kismosari (Rt 05 Rw 2).

Terjadinya peningkatan prevalensi DBD di kedua wilayah ini juga ditambah dengan akses masyarakat yaitu MCK (mandi cuci kakus) yang tersedia secara umum masih dapat dikatakan kurang. Wilayah Kismosari terdiri dari 80 kepala keluarga (KK), namun hanya $15 \mathrm{KK}$ saja yang memiliki MCK secara mandiri di rumah, sedangkan sisanya hanya mengandalkan fasilitas umum MCK dengan jumlah yang sangat terbatas yaitu hanya 4 unit di wilayah tersebut. Tentu saja hal ini berdampak penting terhadap kesehatan bilamana sanitasi dan higienitas tidak dikelola dengan baik maka semakin menambah angka kejadian penyakit seperti typhus, diare dan demam berdarah.

Hasil observasi menunjukkan bahwa telah dilakukan pemeriksaan terhadap jentik nyamuk di lingkungan warga, namun pemeriksaan ini belum dilakukan secara berkala. Pemeriksaan jentik hanya dilakukan jika ada laporan yang ditunjukkan melalui surat resmi dari rumah sakit kepada desa (PKD). Kondisi tersebut juga didukung belum adanya tindakan fogging yang dilakukan di wilayah Badran. Di wilayah Kismosari pernah dilakukan fogging namun sudah sangat lama. Apabila suatu desa terjangkit demam berdarah dan sudah mendapatkan pemeriksaan laboratorium maka harus dilakukan fogging, sebab di daerah tersebut berarti mempunyai potensi untuk berkembang nyamuk pembawa virus demam berdarah.
Belum ada vaksin untuk pencegahan penyakit DBD dan belum ada obat-obatan khusus untuk penyembuhannya, dengan demikian upaya pengendalian DBD tergantung pada pemberantasan nyamuk Aedes aegypti. Sejauh ini program pemberantasan penyakit DBD belum maksimal, karena masih tergantung pada penyemprotan insektisida (fogging) untuk membunuh nyamuk dewasa. Pelaksanaannya pun terbatas karena fogging membutuhkan pengoperasian yang khusus dan biaya yang tinggi.

Tindakan pencegahan dan pemberantasan akan lebih lestari bila dilakukan dengan pemberantasan sumber larva. Dalam hal ini perlu pendekatan yang terpadu terhadap pengendalian nyamuk dengan menggunakan semua metode yang tepat (lingkungan, biologi dan kimiawi) yang murah, aman dan ramah lingkungan (Muhlisin dan Partiwi, 2006).

Pengendalian vektor merupakan metode utama dalam pencegahan DBD karena vaksin dan obat antivirusnya yang efektif belum ada. Pemberantasan larva dengan larvasida menjadi cara pengendalian vektor yang paling efektif. Penggunaan larvasida kimiawi yang mengandung senyawa temefos memberikan efek samping terjadinya resistensi larva Aedes aegypti (Mulyanto dkk, 2012) dan dalam jangka panjang dapat memicu kanker (Panghiyangani, 2012), karena dapat masuk ke rantai makanan dan terakumulasi dalam tubuh (Tiwary dkk, 2007). Oleh karena itu, upaya preventif yang digalakkan melalui kegiatan ini dilakukan menggunakan herbal larvasida, yaitu larvasida yang berbahan dasar herbal berkhasiat yang telah terbukti efektif membunuh larva nyamuk Aedes aegypti. Herbal larvasida digunakan sebagai alternatif pengendalian vektor secara alami yang sederhana, lebih aman dan ramah lingkungan.

Herbal berkhasiat yang digunakan sebagai bahan utama pembuatan herbal larvasida pada kegiatan ini adalah minyak atsiri daun jeruk purut dan sereh dapur, yang kemudian diformulasi menjadi bentuk granul yang mudah larut air. Penelitian Adrianto dkk (2014) menunjukkan bahwa ekstrak daun jeruk purut paling efektif sebagai larvasida alami, karena mampu membunuh 95\% larva Aedes aegypti instar III pada konsentrasi paling kecil dibanding ekstrak daun jeruk limau dan daun jeruk bali, yaitu $0,3176 \%$ setelah 24 jam pendedahan dan $0,2499 \%$ setelah 48 jam pendedahan. Sereh dapur yang telah dibuat granul juga telah teruji efektivitasnya karena mampu membunuh 90\% larva Aedes aegypti instar III pada konsentrasi $0,0051 \%$ setelah dibiarkan terpapar selama 24 jam (Mulyani, 2014).

Upaya preventif yang efektif kedua setelah pengendalian vektor adalah dengan penolak nyamuk. Gigitan nyamuk sangat mengganggu aktivitas, bahkan dapat menyebabkan iritasi dan infeksi kulit, khususnya pada bayi dan balita. Penolak nyamuk yang umum digunakan masyarakat berupa spray aerosol, obat 
nyamuk bakar dan elektrik, serta lotion antinyamuk. Bahan kimia utama yang banyak digunakan sebagai penolak nyamuk adalah N,N-Dietil meta toluamida (DEET) yang terbukti paling efektif namun dapat memicu timbulnya gangguan pernafasan dan iritasi kulit sehingga tidak direkomendasikan bagi bayi dan balita.

Mosquito repellent patch adalah stiker anti nyamuk yang mengandung bahan penolak nyamuk. Stiker penolak nyamuk ini penggunaannya tidak langsung kontak dengan kulit, melainkan dengan cara ditempel pada baju atau tempat tidur sehingga pengguna dapat terhindar dari gigitan nyamuk. Kelebihan penolak nyamuk berbentuk stiker adalah aman bagi kulit sehingga cocok digunakan untuk bayi dan balita. Oleh karena itu, upaya preventif kedua yang digalakkan melalui kegiatan ini dilakukan menggunakan mosquito repellent patch berbahan dasar herbal berkhasiat yang telah terbukti efektif menolak nyamuk Aedes aegypti.

Herbal berkhasiat yang digunakan sebagai bahan utama pembuatan mosquito repellent patch pada kegiatan ini adalah minyak atsiri daun jeruk purut dan sereh dapur. Aktivitas penolak nyamuk dari minyak atsiri daun jeruk purut dan sereh dapur telah diuji oleh Mulyani dkk (2013) dengan kadar efektif berturutturut adalah $20 \%$ dan $40 \%$ dengan penolakan nyamuk $100 \%$ secara berturut-turut terjadi pada menit ke-60 dan ke-30. Selain memiliki khasiat sebagai penolak nyamuk, minyak atsiri daun jeruk purut dan sereh dapur yang terkandung dalam mosquito repellent patch yang dibuat pada kegiatan ini, juga mampu memberikan efek aromaterapi yang segar dan menenangkan bagi pengguna, aman dan ramah lingkungan.

Upaya kuratif yang utama pada penanganan DBD ditekankan pada peningkatan kadar trombosit dan daya tahan tubuh. Pemanfaatan herbal berkhasiat dengan kandungan utama daun ubi jalar, digunakan sebagai upaya kuratif untuk meningkatkan kadar trombosit pada penanganan DBD di desa Gadingan. Produk disajikan dalam bentuk teh herbal, yaitu produk berbahan dasar herbal yang dibuat dari bagian tanaman yang dikeringkan dan dihaluskan, yang dikonsumsi dengan cara diseduh sebagaimana lazimnya meminum teh. Air rebusan daun ubi jalar mampu meningkatkan kadar trombosit (Widyastuti, 2016). Aktivitas kandungan zat aktif dalam daun ubi jalar sebagai antioksidan sangat mendukung dalam peningkatan daya tahan tubuh yang sangat dibutuhkan dalam pengobatan DBD.

Berdasarkan pengamatan dan observasi baik di Kismosari dan Badran, masyarakat banyak yang memiliki tanaman jeruk purut, sereh dapur dan ubi jalar. Sejauh ini pemanfaatan tanaman tersebut hanya terbatas pada penggunaannya sebagai bahan masak atau bumbu masak dan belum digunakan untuk tujuan terapi maupun pengobatan. Hal ini terjadi karena masih rendahnya pemahaman masyarakat tentang pemanfaatan tanaman berkhasiat untuk kesehatan. Oleh karena itu melalui kegiatan ini, masyarakat di kedua wilayah mitra desa Gadingan diharapkan mampu memanfaatkan herbal berkhasiat yang ditanam di lingkungan sekitar untuk dibuat menjadi produk berupa mosquito repellent patch, herbal larvasida, dan teh herbal yang dapat digunakan dalam upaya preventif dan kuratif dalam meminimalisir dampak DBD.

Selain untuk menekan angka kejadian DBD di desa Gadingan, terciptanya produk herbal berkhasiat berupa mosquito repellent patch, herbal larvasida, dan teh herbal juga diharapkan menjadi produk unggulan desa Gadingan. Melalui pembentukan kelompok wirausaha dengan kepengurusan yang terstruktur, produk herbal berkhasiat berupa mosquito repellent patch, herbal larvasida, dan teh herbal juga dapat dikembangkan menuju arah komersial. Dengan demikian diperoleh dua manfaat sekaligus, yaitu peningkatan derajat kesehatan dan peningkatan perekonomian masyarakat wilayah mitra di desa Gadingan.

\section{METODE PELAKSANAAN}

Pelaksanaan program kemitraan masyarakat mengambil lokasi desa Gadingan dengan dua wilayah mitra yang dipilih yaitu Kismosari dan Badran. Waktu pelaksanaan program kemitraan masyarakat dari bulan Juli-Oktober 2017. Pengabdian kepada masyarakat dengan program kemitraan masyarakat dilaksanakan melalui serangkaian tahapan seperti disajikan pada gambar 1 . 


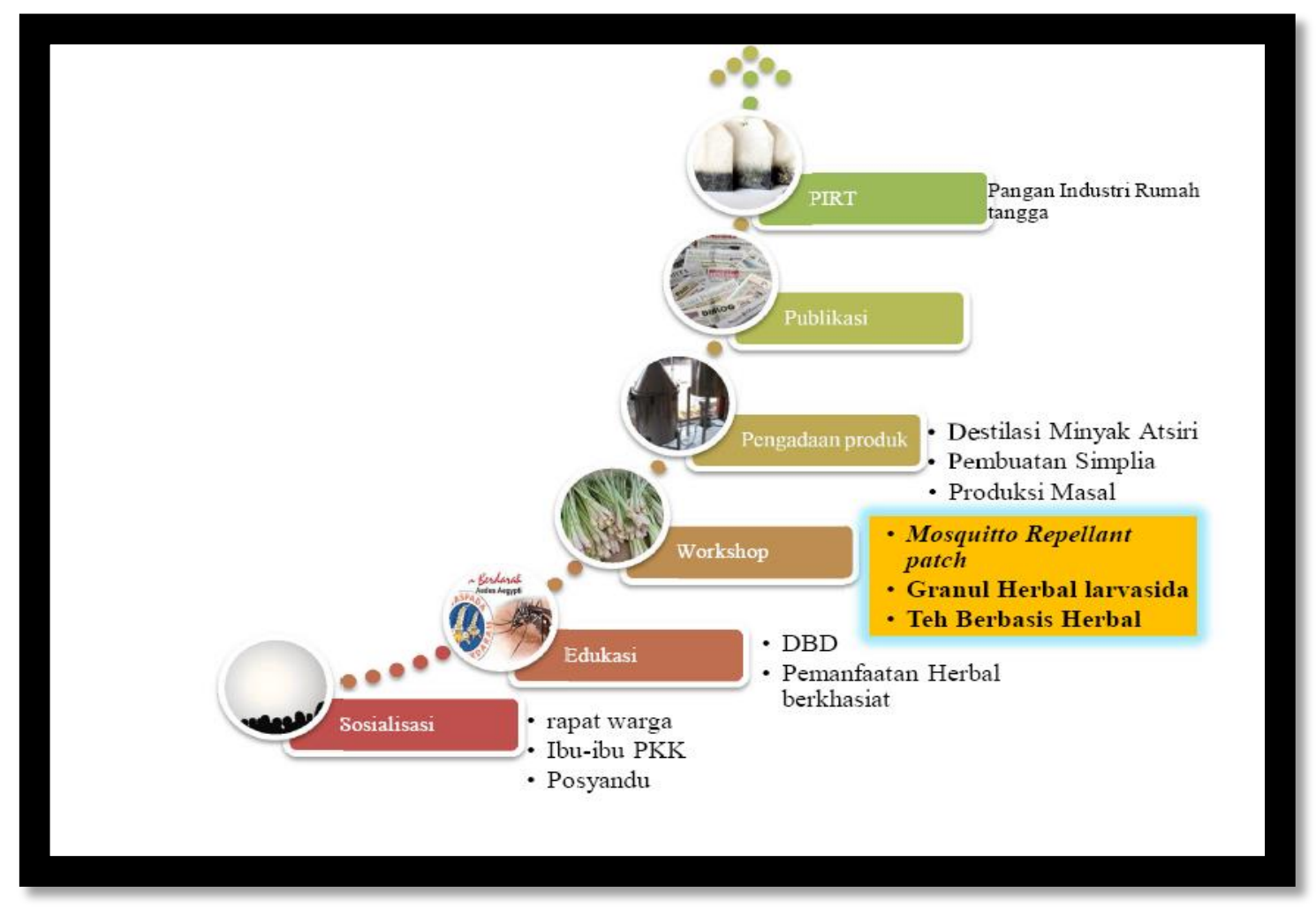

Gambar 1. Tahapan pelaksanaan program

Kegiatan diawali dengan melakukan sosialisasi program, diikuti dengan edukasi DBD dan pemanfaatan herbal berkhasiat, yang disertai dengan pelatihan herbal berkhasiat. Selanjutnya potensi herbal berkhasiat wilayah mitra diaplikasikan dengan pembuatan produk yaitu mosquito repellent patch, granul herbal larvasida dan teh herbal. Pengadaan produk dilakukan oleh warga kedua wilayah mitra dengan pendampingan tim pelaksana yang melibatkan mahasiswa dan stakeholder.

Monitoring evaluasi terhadap program edukasi dilakukan dengan pretest dan posttest untuk mengukur tingkat pengetahuan warga. Pengembangan produk dilakukan dengan melihat hasil evaluasi mitra pada saat pelaksanaan pelatihan herbal berkhasiat. Evaluasi keberhasilan program dilihat dengan beberapa indikator yaitu: tingkat pengetahuan warga terhadap DBD pasca edukasi, peningkatan daya saing yang ditunjukkan dengan pengembangan produk herbal berkhasiat dan munculnya kelembagaan untuk keberlanjutan program.

\section{HASIL DAN PEMBAHASAN}

Kegiatan program kemitraan masyarakat dengan mitra Kismosari dan Badran berlangsung selama 4 bulan dengan tahapan kegiatan yang berjalan secara berkelanjutan. Dalam menjalankan kegiatan, tim menjalin kerjasama dengan mahasiswa dan stakeholder, yaitu Dinas Kesehatan Kabupaten Sukoharjo.
Pada tahap sosialisasi dilakukan pengenalan terhadap Program Kemitraan Masyarakat yang ditekankan pada latar belakang, tujuan dan manfaat pemilihan program kegiatan, pemilihan wilayah mitra dan hasil analisis situasi, serta tahapan-tahapan kegiatan yang akan dilakukan. Kegiatan sosialisasi diikuti oleh perangkat RT dan RW, perwakilan paguyuban bapak-bapak dan sebagian besar adalah ibu-ibu PKK di kedua wilayah mitra.

Pada kegiatan program edukasi di wilayah mitra Kismosari diikuti oleh 75 warga sedangkan untuk pelaksanaan di wilayah Badran diikuti oleh 50 warga yang meliputi perwakilan paguyuban bapak-bapak dan ibu-ibu PKK. Kegiatan program edukasi dilaksanakan dalam dua segmen. Dokumentasi kegiatan edukasi disajikan pada gambar 2 .
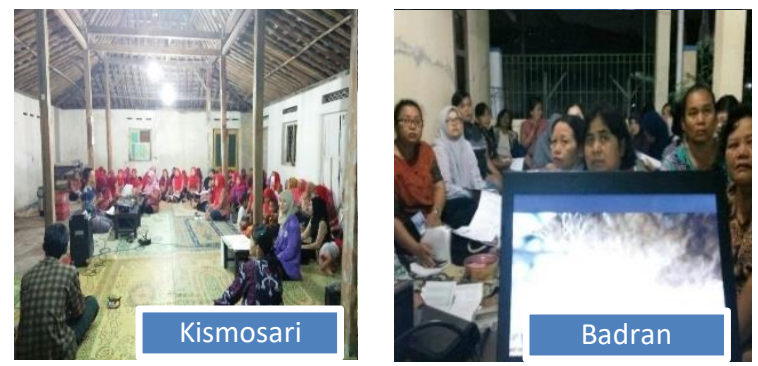

Gambar 2. Pelaksanaan program edukasi

Segmen pertama yaitu Edukasi Deman Berdarah Dengue. Kegiatan ini dilaksanakan untuk meningkatkan pengetahuan masyarakat terkait faktor pemicu, gejala dan pertolongan pertama apabila 
terkena DBD. Melalui proses edukasi yang dilaksanakan secara berkala diharapkan mampu meningkatkan kepedulian masyarakat tentang pentingnya menjaga lingkungan, pentingnya aspek sanitasi dan higienitas untuk meminimalisir dampak DBD lebih lanjut. Edukasi dilakukan melalui media TVC yang mampu memberikan gambaran secara nyata tentang upaya preventif untuk DBD. Pada pemaparan materi dijelaskan pula patofisiologi terjadinya DBD sehingga diharapkan masyarakat mengetahui tanda gejala DBD.

Pada segmen kedua dilakukan edukasi tentang herbal berkhasiat. Potensi tanaman (herbal) di desa Gadingan khususnya di wilayah mitra Kismosari dan Badran menjadi hal penting, mengingat masyarakat belum mengenal secara luas tentang manfaat secara spesifik tanaman herbal untuk penanganan pertama bila terjadi resiko penyakit DBD. Edukasi ditekankan pada pemanfaatan bahan herbal berkhasiat di lingkungan sekitar yang secara praktis dapat digunakan oleh masyarakat. Paparan pemanfaatan herbal berkhasiat dilakukan dengan menggunakan bahan herbal yang disesuaikan dengan target untuk upaya preventif dan kuratif DBD. Pada paparan materi yang disampaikan setidaknya terdapat 4 target penggunaan herbal berkhasiat dalam pengobatan yaitu: meningkatkan trombosit, menurunkan demam, meningkatkan daya tahan tubuh, menolak gigitan nyamuk (repellent). Berdasarkan informasi yang telah diperoleh, banyak warga masyarakat mitra yang belum mengetahui pemanfaatan herbal yang dapat digunakan sebagai upaya preventif dan kuratif DBD.

Pengukuran efektivitas keberhasilan kegiatan edukasi DBD dan pemanfaatan herbal berkhasiat dilakukan dengan pretest dan posttest. Hasil yang diperoleh menunjukkan terdapat perubahan nilai ratarata dari yang sebelumnya 45 pada pretest menjadi 73 pada posttest, seperti disajikan pada gambar 3. Hal ini memberikan gambaran adanya manfaat yang muncul dari pelaksanaan edukasi program DBD dan pemanfaatan herbal berkhasiat. Bertambahnya pengetahuan pada warga wilayah mitra ini menjadi salah satu modal dasar yang nantinya dapat digunakan untuk upaya preventif sejak dini terhadap penyakit DBD.

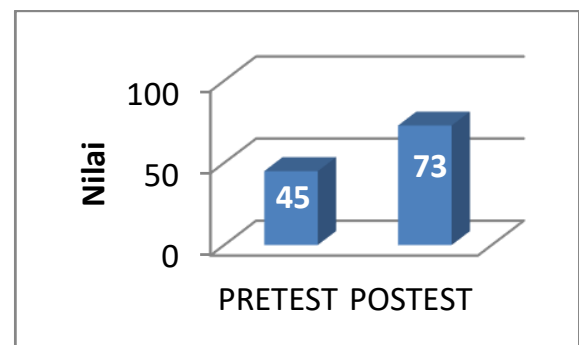

Gambar 3. Hasil evaluasi program edukasi

Program pelatihan memberikan gambaran tentang upaya yang dapat dilakukan untuk mengembangkan bahan herbal berkhasiat yang bisa ditemukan di lingkungan sekitar. Pengembangan bahan herbal diwujudkan menjadi produk yang dapat diaplikasikan untuk upaya preventif dan kuratif DBD. Beberapa bahan herbal yang digunakan antara lain: daun ubi jalar, herba meniran, daun stevia, daun jeruk purut (minyak atsiri), sereh dapur (minyak atsiri). Bahan-bahan tersebut selanjutnya dikembangkan menjadi 3 produk yaitu mosquito repellent patch, granul larvasida dan teh herbal. Pembuatan produk saat pelatihan pengembangan herbal berkhasiat ini dilakukan dalam kondisi produk setengah jadi, yaitu beberapa bahan dasar disiapkan dalam bentuk siap digunakan antara lain: simplisia yang telah dipulverisasi dan minyak atsiri yang sudah siap digunakan. Produk hasil pelatihan diberikan langsung kepada warga untuk dapat diaplikasikan dan dievaluasi. Dokumentasi kegiatan pelatihan disajikan pada gambar 4 dan 5 .
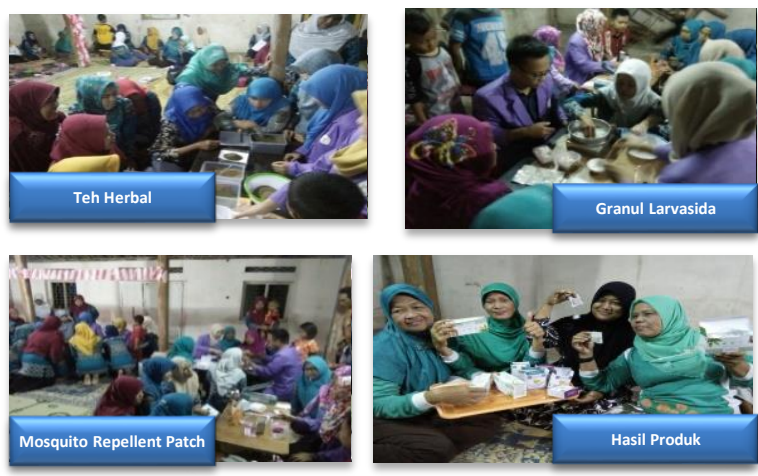

Gambar 4. Pelatihan di wilayah Kismosari
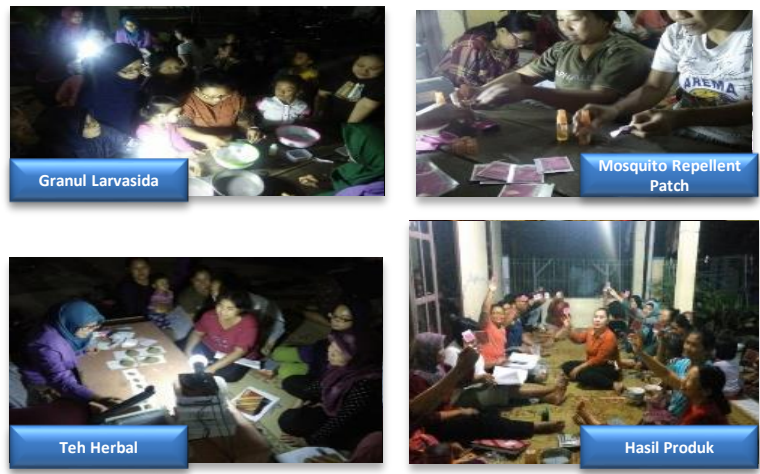

Gambar 5. Pelatihan di wilayah Badran

Monitoring evaluasi dilakukan sebagai salah satu langkah untuk menilai keberlanjutan program dan menilai antusias masyarakat berdasarkan kegiatan yang telah dilakukan oleh tim program kemitraan masyarakat. Pada kegiatan monitoring dan evaluasi warga masyarakat diminta untuk menilai 3 produk dari hasil pelatihan yang telah dilakukan dalam pertemuan sebelumnya. Evaluasi dari tiga produk dilakukan dengan memberikan quisioner untuk masing-masing produk dengan 5 parameter yaitu: inovasi produk, kombinasi bahan, organoleptis (rasa, bentuk, tekstur, bau), penampilan, dan manfaat. 
Berdasarkan hasil evaluasi terhadap penggunaan produk di wilayah mitra baik Kismosari dan Badran diperoleh rekapitulasi hasil di Desa Gadingan sebagaimana disajikan pada gambar 6, yaitu 55,68\% warga menyukai produk teh herbal, disusul 30,68\% pada mosquito repellent patch dan $13,64 \%$ pada produk granul larvasida. Berdasarkan hasil analisis di masing-masing mitra diperoleh rekomendasi pengembangan terhadap 2 produk yaitu teh herbal untuk wilayah mitra Kismosari dan mosquito repellent patch untuk wilayah mitra Badran. Beberapa hal yang menjadi dasar pemilihan terhadap produk ini adalah peluang pengembangan produk jangka panjang, nilai komersial produk dan pemasaran secara luas dengan label PIRT (Pangan Industri Rumah Tangga) untuk teh herbal dan inovasi produk yang dinilai untuk mosquito repellent patch.

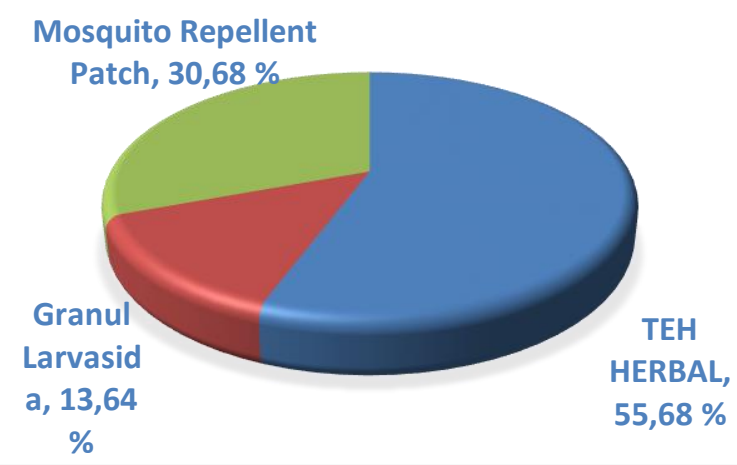

Gambar 6. Hasil evaluasi penggunaan produk

Pada tahap berikutnya dilakukan evaluasi terhadap tiap produk untuk mengetahui kualitasnya dengan hasil disajikan pada gambar 7. Berdasarkan hasil rata-rata evaluasi dari ketiga produk dinilai baik 53 $\%$ dan sangat baik $25,7 \%$, cukup $19 \%$ dan $2,3 \%$ dinilai kurang. Hal ini menunjukkan bahwa pengembangan produk yang dilakukan melalui kegiatan pelatihan sangat berpotensi untuk dikembangkan lebih lanjut.

Sebagai keberlanjutan program, dilaksanakan pengadaan produk untuk teh herbal dan mosquito repellent patch dengan kapasitas produksi yang lebih besar. Proses pengadaan produk pada masingmasing wilayah mitra sesuai dengan hasil evaluasi yang telah dilakukan sebelumnya. Pada tahap pengadaan produk warga masyarakat mitra menyiapkan seluruh bahan dasar secara mandiri. Proses produksi teh herbal di Kismosari dilakukan dengan target produksi 600 kantong teh atau setara dengan 24 box karton@ 25 pcs kantong teh. Berbeda dengan di wilayah mitra Kismosari, warga di wilayah Badran menyiapkan batang sereh dan daun jeruk dalam kondisi segar untuk kemudian dilakukan proses destilasi dengan hasil akhir minyak atsiri. Pengadaan produk mosquito repellent patch dilakukan dengan kapasitas produksi 200 pcs atau setara dengan 20 box dengan@10 pcs mosquito repellent patch. Rincian jumlah bahan yang dibutuhkan untuk proses produksi disajikan pada tabel I dan II. Dokumentasi kegiatan pengadaan produk disajikan pada gambar 8 .

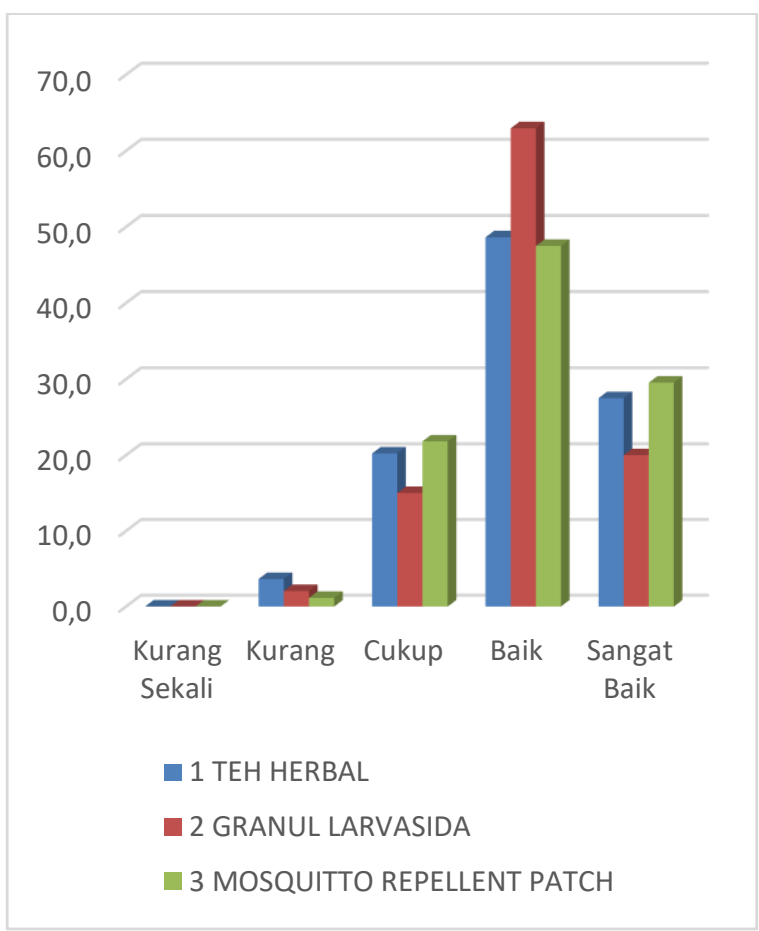

Gambar 7. Hasil evaluasi produk
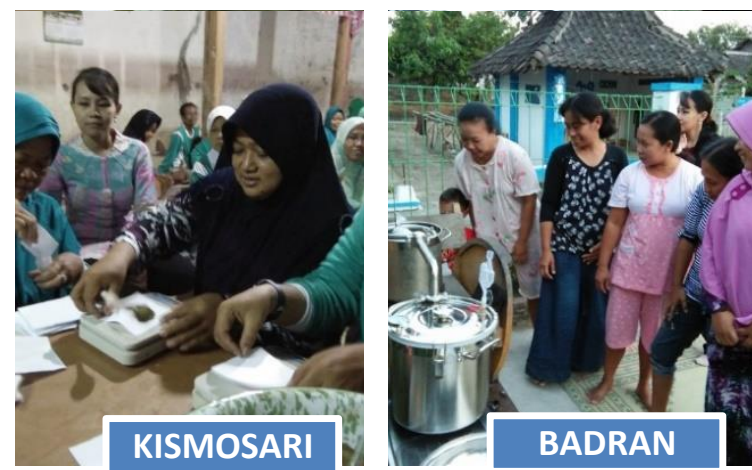

Gambar 8. Pengadaan produk

Pada tahap pengembangan produk atau produksi skala masal, tim program kemitraan masyarakat sekaligus mengenalkan nama atau Brand yang nantinya digunakan dalam proses berikutnya, yaitu tahap publikasi, launching produk dan pemasaran. Ketiga produk tersebut diberi nama LARVIA dengan spesifikasi sesuai dengan diferensiasi produk seperti disajikan pada gambar 9 . 
Tabel 1. Komposisi Teh Herbal

\begin{tabular}{c|l|c|c}
\hline No & \multicolumn{1}{|c|}{ Komposisi } & $\begin{array}{c}\text { Jumlah } \\
(\mathrm{g}) / \text { kantong }\end{array}$ & $\begin{array}{c}\text { Jumlah Skala Produksi } \\
(\mathrm{g})\end{array}$ \\
\hline 1 & Daun Ubi Jalar & 1.5 & 900 \\
2 & Menira Herba & 0,5 & 300 \\
3 & Daun Stevia & 1.0 & 600 \\
\hline
\end{tabular}

Tabel 2. Komposisi mosquito repellent patch

\begin{tabular}{c|l|c|c}
\hline No & \multicolumn{1}{|c|}{ Komposisi } & Jumlah (\%)/patch & $\begin{array}{c}\text { Jumlah Skala Produksi } \\
(\mathrm{mL})\end{array}$ \\
\hline 1 & Minyak Daun Jeruk & 7,5 & 7,5 \\
2 & Minyak Sereh & 10 & 10 \\
3 & Propylenglicol & 20 & 20 \\
4 & Alcohol 96\% & 62,5 & 62,5 \\
\hline
\end{tabular}

Keterangan: 1 patch diberikan 2 kali spray formula yang setara dengan $500 \mu \mathrm{g}$.
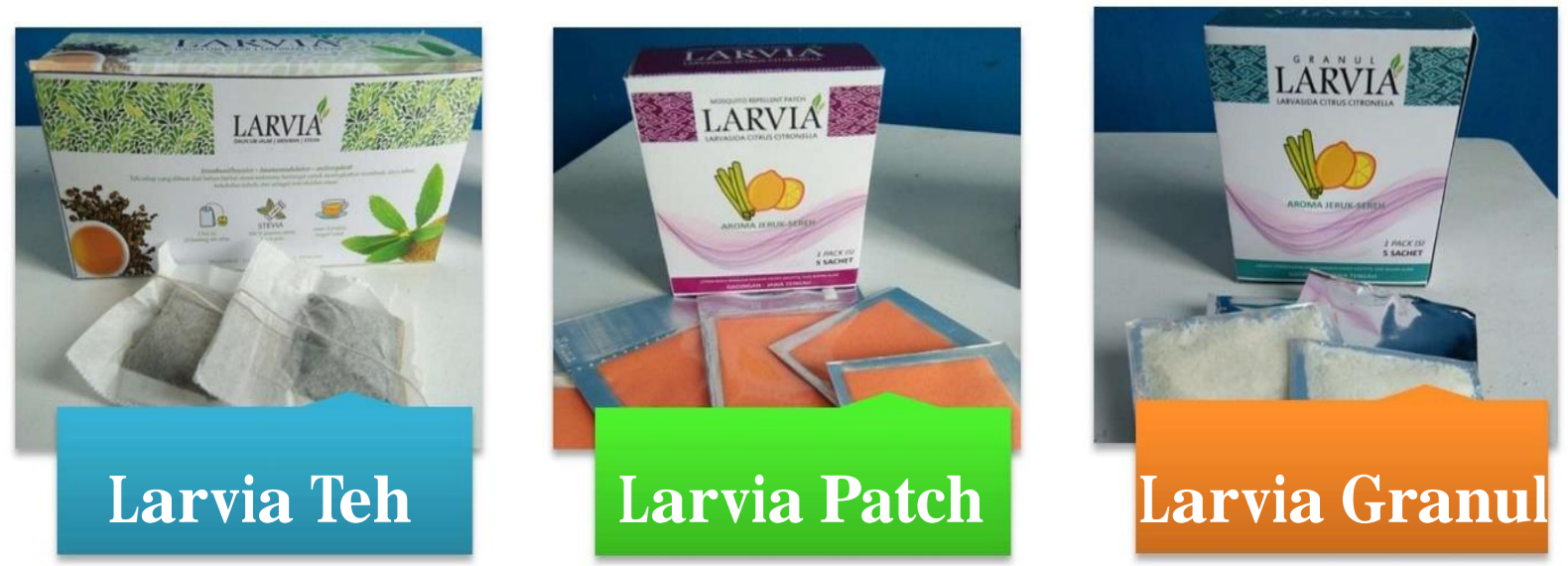

Gambar 9. Produk jadi LARVIA teh, patch, dan granul

\section{KESIMPULAN}

Program kemitraan masyarakat yang telah dilaksanakan mampu mencapai tujuan kegiatan yaitu masyarakat wilayah mitra di desa Gadingan dapat menerapkan upaya preventif dan kuratif DBD melalui pemanfaatan herbal berkhasiat yang ditanam di lingkungan sekitar. Upaya preventif dilakukan dengan pemberantasan larva menggunakan granul herbal larvasida dan menghindari gigitan nyamuk menggunakan mosquito repellent patch yang keduanya berbahan aktif minyak atsiri daun jeruk purut dan sereh dapur. Upaya kuratif dilakukan dengan mengkonsumsi teh herbal yang berbahan aktif daun ubi jalar sebagai terapi suportif untuk meningkatkan trombosit dan daya tahan tubuh. Tentu saja hal ini berdampak pada semakin membaiknya derajat kesehatan warga masyarakat yang dilihat dari angka kejadian DBD pada tahun 2017 yang mengalami penurunan bila dibandingkan dengan data pada saat survey dilaksanakan (2016). Pada tahun 2016 terjadi insiden 4 warga terjangkit DBD di wilayah Badran dan 2 warga di wilayah Kismosari. Pada tahun 2017 angka kejadian insiden DBD berkurang menjadi 1 warga di wilayah Badran. Bilamana upaya preventif dan kuratif melalui pemanfaatan herbal berkhasiat diimplementasikan kepada khalayak yang lebih luas, baik secara operasional maupun produk yang dihasilkan, maka kebermanfaatannya akan berimplikasi pada penekanan angka kejadian DBD dengan wilayah yang lebih luas, khususnya di daerah endemis demam berdarah dengan Case Fatality Rate (CFR) yang tinggi.

Peningkatan daya saing (peningkatan kualitas, kuantitas serta nilai tambah barang, jasa, diversifikasi produk, atau sumber daya lainya) diwujudkan dengan adanya pengembangan produk herbal berkhasiat. Produk yang dihasilkan dikembangkan menuju arah komersial yaitu dengan label izin edar PIRT untuk produk teh herbal. Bilamana upaya ini diimplementasikan pada khalayak yang lebih luas maka secara kebermanfaatan akan berdampak pada bertambahnya kelompok wirausaha masyarakat yang mengembangkan produk berbahan aktif herbal berkhasiat. Dengan demikian diperoleh dua manfaat 
sekaligus, yaitu peningkatan derajat kesehatan dan peningkatan perekonomian masyarakat.

\section{UCAPAN TERIMA KASIH}

Terima kasih disampaikan kepada Kemenristek DIKTI yang telah mendanai keberlangsungan program ini melalui Hibah Program Kemitraan Masyarakat 2017.

\section{DAFTAR PUSTAKA}

Adrianto, H., Yotopranoto, S., dan Hamidah. (2014). Efektivitas Ekstrak Daun Jeruk Purut (Cytrus Hystrix), Jeruk Limau (Cytrus amblycarpa), dan Jeruk Bali (Citrus maxima) terhadap Larva Aedes aegypti. Aspirator, 6(1), 1 - 6.

Dinkes Sukoharjo. (2014). Profil Kesehatan Sukoharjo 2014. Sukoharjo.

Muhlisin dan Partiwi. (2006). Penanggulangan Demam Berdarah Dengue (DBD) di Kelurahan Singopuran Kartasura Sukoharjo. WARTA, 9(2), 123 - 129.

Mulyani, S. (2014). Granul Minyak Serai Dapur sebagai Larvasida Nyamuk Aedes aegypti. Trad. Med.J., 19(3), 138 - 141.

Mulyani, S., Mulyaningsih, B., Lestari, A.W., Ana, F., Anna, D.S. (2013). Insence Combustible Sereh, Cengkeh, Daun Jeruk sebagai Penolak Nyamuk Aedes aegypti. Trad. Med. J., 18(3), 195- 200.

Mulyanto, K.C., Yamanaka, A., Ngadino, Konishi, E. (2012). Resistance of Aedes aegypti to Temephos in Surabaya Indonesia. Southeast Asian Journal Tropical Medicine Public Health, 43(1), 29 - 33.

Panghiyangani, R., Marlinae, L., Yuliana, Fauzi, Noor, D., Anggriani. (2012). Larvaside Effect of Tumeric Rhizome Extract (Curcuma domestica) on Dengue Hemorrhagic Fever Aedes aegypti in Banjarbaru. Jurnal Epidemiologi dan Penyakit Bersumber Binatang, 4(1), $1-6$.

Tiwary, M., Nanik, S.N, Tewary, D.K., Mittal, Yadav. (2007). Chemical Composition and Larvacidal Activities of The Essential Oil of Zanthoxylum armatum DC Agains Three Mosquito Vectors. Journal Vector Borne Disease, 44, 198 - 204.

Widyastuti, R. (2016). Pengaruh Pemberian Air Rebusan Daun Ubi Jalar (Ipomea batatas) terhadap Peningkatan Jumlah Trombosit Mencit (Mus musculus). The Journal of Muhammadiyah Medical Laboratory Technologist, 2(2), 60 - 69. 